\title{
The politics of sovereignty and space ${ }^{1}$
}

Politics, for the Arab philosopher Khaldun, concerns 'the administration of home or city in accordance with ethical and philosophical requirements, for the purpose of directing the mass toward a behaviour that will result in the preservation and permanence of the (human) species.'. This quest for survival, at the heart of Khaldun's understanding of politics, raises a number of fundamental questions about space, law, security and ultimately survival, which remain pertinent today. The questions emerging from Khaldun's work are certainly apt when discussing the contemporary Middle East, where the construction of political organisation has been directed towards the regulation of life. This chapter explores the way in which life has been regulated across the space of sovereign states, drawing on the work of Giorgio Agamben, Hannah Arendt, Robert Cover, Gilles Deleuze and Felix Guattari.

Although the concept of the sovereign state is one that is traditionally associated with European political philosophy, states have manifested across the region as the contemporary form of political organisation, replacing the tribe, umma, khalifa and sultanate, which had regulated life prior to the demise of the Ottoman Empire. According to Charles Tilly, the dominance of the European view is a consequence of three hundred years of Europeans and their descendants imposing their system on the world. ${ }^{3}$ Of course, states that were imposed three hundred years ago are vastly different to their modern relations, stemming from developments in all forms of life; the modern nation state is an altogether different beast albeit one that continues to interact with the legacy and memory of what came before.

Debate over the imposition and the creation of artificial political projects by external powers - referred to as 'the original sin of state creation' by Ghassan Salame - has been a prominent feature of discussions of state formation and state building in the politics of the region. ${ }^{4}$ While often viewed as artificial entities and condemned as impotent, states largely remain intact into the twenty-first century, predicated upon a range of context-specific contingent factors that shape the nature of social contracts and political life. Yet questions about the very nature of the state and sovereignty continue to dominate intellectual discussion. 
A great deal of work has been undertaken on states and their claims to sovereign power. Focusing on the Middle East, scholars including Nazih N. Ayubi, Roger Owen, Lisa Anderson, Charles Tripp, Sami Zubaida, Fred Halliday, Philip S. Khoury, Joseph Kostiner, Raymond Hinnebusch and Fouad Ajami (among others) have all engaged with such projects with a variety of different conclusions. ${ }^{5}$ Although taking divergent theoretical, ontological and conceptual approaches, these works trace the development and interaction of states, peoples, bureaucracies and ideologies, focusing upon different loci of power and the spatial repercussions of such projects.

Acknowledging the important contributions made by these authors, I endorse Joel Migdal's definition of the state as:

[An] organization, composed of numerous agencies led and coordinated by the state's leadership (executive authority) that has the ability or authority to make and implement the binding rules for all the people as well as the parameters of rule making for other social organizations in a given territory. ${ }^{6}$

Following Charles Tripp, I also view the state as a consequence of performability, an ongoing process that refutes the 'fixed' nature of states. In accepting this, I view states as political projects that are shaped and reshaped by the context and contingency of spatial dynamics. In times of crisis, performances draw upon a range of different forms of symbolic capital to maintain or re-establish the state, yet such processes often lead to contestation within domestic borders and across the region.

State-building processes are typically understood by considering the work of Charles Tilly, whose thesis 'war made the state and the state made war' offers a convincing account of the development of state institutions. ${ }^{7}$ Within debate and reflection on the nature of statehood, comparisons are often made with European states and the Weberian 'ideal' type, which bring together concepts of security, welfare and representation. Yet as Rolf Schwarz argues, perhaps this ideal type is the exception, not the rule; instead, regulating interactions in a number of context-specific ways. ${ }^{8}$ While the Middle East has been shaped, and perhaps in the middle of the twentieth century characterised, by violent conflict, territorial gain was not always the primary goal. ${ }^{9}$ The rapid militarisation of the Middle East supports this premise, increasing insecurity as a consequence, yet closer examination reveals that conflict has been facilitated by the massive extraction of rent derived from natural resources ${ }^{10}$ often viewed as 'the gift from nature' facilitating regime survival.

Within debate on political systems and state-society relations in the Middle East there is typically a conflation between state, sovereign, government and regime. This is deeply problematic and before we move forward, we must quickly distinguish between different typologies. Regimes are more permanent representations of political organisation than governments or leaders, but they are less permanent than the state. Regimes typically pre-date both the state and nation ${ }^{11}$ thus state- and nation-building projects are driven by regimes, with their own survival at the forefront of political projects. They are a product of their historical environment, shaped by the interaction 
of a number of competing identities and ideologies. With this in mind, the state is taken as a 'more permanent structure of domination and coordination including a coercive apparatus and the means to administer a society and extract resources from it. ${ }^{12}$ Thus, domestic sovereignty is the ability to regulate life based upon the contextspecific relationship between ruler and ruled that is shaped by a range of contingent factors. Thus, to understand the emergence of states across the Middle East we must follow Albert Hourani's lead and retain that which was previously discarded. ${ }^{13}$

While discussion of statehood is certainly of paramount importance, it is here where I depart from other scholars, choosing instead to focus upon the concept of sovereignty as the lens through which interactions are regulated rather than discussing typologies of political organisation. As Talal Asad articulates, the state, 'independently of the entire population, embodies sovereignty' ${ }^{14}$ but the separation of sovereignty from state poses a range of challenges. As Lisa Anderson notes in a brief bibliography on the concept of the state in the Arab world, this approach of ungluing sovereignty from statehood is potentially disconcerting on normative grounds as sovereign power may be 'reattached' to monarchs, princely families or even firms. ${ }^{15}$ I do not go quite so far in my analysis. Instead, I argue that such an approach is necessary to understand the claims to power made by regimes and from this, the way in which political life is contested. Ultimately, focusing on sovereignty allows for exploration of political communities and their relationship with both territory and regional dynamics.

Inherent to the parabolic pressures that forge states are innumerable forms of contestation. To ensure survival, rulers have imposed political, legal and economic structures to secure their rule, creating order within space while also cultivating narratives to increase legitimacy and recognition among both internal and external audiences. Several states have referred to pan-state ideologies - Arabism and Islamism - in an effort to unite peoples across the region, which has often been driven by national interest. ${ }^{16}$ More recently, ideas of sectarian unity have been used to construct membership of a shared community against an 'other' that is often perceived to possess nefarious intent. This reference to pan-state ideologies which transcend state borders and political organisation reveals the presence of a shared normative environment, which poses serious challenges to state sovereignty and the Westphalian principle of 'non-interference. ${ }^{17}$ Referring to leadership of the $u m m a^{18}$ has led some to suggest that dawla (states) have no real power and that true authority - sovereignty can only be found in God and membership of the umma.

Such challenges emerging from the relationship between religion and politics are not restricted to Islam and are perhaps more obvious in the complex relationship between the state of Israel and myriad sects of Judaism, where competing visions of political organisation define the spatial limits of the state. The most prominent example of such contestation is apparent in the building of settlement outposts in the West Bank. which is sometimes undertaken by the state but also undertaken by groups contesting the state's authority. Organisations such a Gush Emunim and the Hilltop Youth have conducted 'price tag' attacks against the state and Palestinians while also rejecting the legitimacy of the state of Israel, in a number of cases, seeking to bring 
about its downfall. Recent estimates suggest that over five hundred thousand people live in settlements - some of which are sanctioned by the state - in the West Bank, with a growing number living in Area B, in breach of the Oslo Accords. ${ }^{19}$ Of course, questions about the territorial limits of political organisation play an increasingly important role in the nature of state sovereignty and the relationship between regimes and people, within and across space.

From the Sykes-Picot agreement until the present day, external powers have played a prominent role in shaping the nature of regional politics and the daily life of individuals, albeit with tensions emerging between states and global economic forces. ${ }^{20}$ The legacy of colonialism is easily seen in the development of political organisation across the region. From the residue of the Ottomans to mandates and the role of British agents across the Gulf, the prominence of external actors in shaping political structures must not be ignored. ${ }^{21}$ For some, the very existence of the state is evidence of this colonial legacy, viewing the emergence of the contemporary state as the impact of Western forces. Yet in acknowledging such a position, one has to be careful not to deny native agency to those involved in political life, as local contexts feature prominently in the construction of political life and the regulation of space.

Penetration also takes place through the emergence of a global economy and actions of private companies and individuals who continue to reproduce economic, political and legal structures that feed into the (re)construction of the sovereign state. While the discovery of oil was heralded to facilitate autonomy and strength across the region, the patron-client relationships that emerged contributed to economic structures shaping dependency across the region. ${ }^{22}$ Over time these relationships have changed, but patron-client relations continue to penetrate - and shape - the region, through helping define the spatial limits of political projects but also the capacity of sovereign power itself. ${ }^{23}$

\section{The history of an idea}

If one is asked to trace the roots of the sovereign state, one typically begins with the 1648 Peace of Westphalia, which established the principle of non-interference based upon the premise of states possessing exclusive authority within their territorial borders. ${ }^{24}$ The peace treaties signed at Munster and Osnabruck established the inviolable norm of non-interference within the domestic affairs of other states, enshrining borders, security and order within relations between different states defined by spatial boundaries. Of course, the structure of such forms of organisation differs, shaped by time, space and local traditions, yet the principle of noninterference remains central.

Over the years, scholars have sought to trace the philosophical roots of sovereignty and with it, constituent parts of the idea, with a recent focus on the ordering of life. The opening line of Political Theology, Carl Schmitt's seminal work that would shape scholarly work on the concept of sovereignty in the coming years, clearly articulates his position: 'Sovereign is he who decides on the exception. ${ }^{25}$ Schmitt's thought posits the 
state of exception as a paradigm of government that, as Agamben later suggests, 'has today reached its full development. ${ }^{26}$

Building upon Schmitt and Foucault - along with others including Hannah Arendt and Walter Benjamin - Agamben's Homo Sacer project is grounded in biopolitics, concerned with the organisation and control of human life through the governance power of the state. Ultimately, it is an approach concerned with inclusion through exclusion. Fundamental to this is the sovereign decision over where the law applies and where it does not. For Agamben, 'the rule, suspending itself, gives rise to the exception and, maintaining itself in relation to the exception, first constitutes itself as a rule. ${ }^{27}$

Within this 'paradigm of government', Agamben suggests that the law 'encompasses living beings by means of its own suspension', controlling life through locating bare life at the forefront of politics, rejecting the rule of law in the process. ${ }^{28}$ Fundamental to this line of thought is the idea that 'the state of exception is the preliminary condition for any definition of the relation that binds and at the same time abandons the living being to the law, ${ }^{29}$ deciding which forms of life are worth living in the process.

As Agamben argues,

[T] he realm of bare life - which is originally situated at the margins of the political order - gradually begins to coincide with the political realm, and exclusion and inclusion, outside and inside, bios and zoe, right and fact, enter into a zone of irreducible indistinction. At once excluding bare life from and capturing it within the political order, the state of exception actually constituted, in its very separateness, the hidden foundation on which the entire political system rested..$^{30}$

Within the state of exception, the sovereign differentiates between the realms of bios and zoe, creating a binary distinction between those recognised as fully human through their participation in political life and those who are outside, where political life and meaning is stripped from them, creating a zone of indistinction and bare life. The marginalisation of people into the condition of bare life can occur as a consequence of a number of different processes, yet in attempting to escape these conditions, violent dislocations occur between regimes and society.

Central to Agamben's project is the idea of the camp, the 'hidden paradigm of the political space of modernity', a site of possibility as well as a specific area within which life is stripped of meaning. ${ }^{31}$ The camp is a spatial-ontological arena, a space of possibility and the link between localisation and ordering. Fundamentally it is a spatial construct, existing beyond the normal juridical and governmental order, with implications for ordering international politics. ${ }^{32}$ The camp emerges when the exception becomes the rule, in specific sites but also as a broader space of metaphysical possibility, which creates the conditions within which human life may be reduced to bare life. ${ }^{33}$ Although a space of exception, the physical manifestation of the camp exists as a territorial area that lies beyond the juridical order, the production of a spatial exception, inscribing exclusion through inclusion. ${ }^{34}$ 
In The Kingdom and the Glory, Agamben builds upon these ideas, arguing that 'the real problem, the central mystery of politics is not sovereignty, but government ... it is not the law, but the police - that is to say, the governmental machine that they form and support' (emphasis in original). ${ }^{35}$ In a complex yet persuasive argument, he suggests that politics is comprised of the constituent parts of government structures that build the mechanisms of the state. Identifying and engaging with these structures is then imperative when considering political change and its processes. ${ }^{36}$ This distinction between government machinery and those constrained by it provides an opportunity to differentiate between rulers and ruled, between regimes and society and it is here where we can build upon Agamben's work to allow for greater discussion of the contemporary Middle East.

In such conditions, the metaphysical constitution of the state, encapsulated in the concept of sovereignty, 'gives birth to law ${ }^{37}$ and ultimately, the state of exception and the ban. Legal structures, institutions and the zone of indistinction do not exist in a vacuum; rather, they are contingent upon and shaped by conditions and cultural relations that are prominent features of political organisation. Efforts to understand such dynamics in the aftermath of state formation have been all too quick to discard the legacy of tradition, as Hourani argues, disregarding what was retained ${ }^{38}$ and what continued to shape interactions within the political and institutional fabric of the state. Such a position stresses the importance of considering both formal and normative structures in shaping the ban and the regulation of life. ${ }^{39}$

Yet in cases of severe contestation, the regulation of life is not sufficient as a means of articulating sovereign power. Although sovereign power exists within localised and ordered space, when spatial borders and the means through which space is ordered become contested, sovereign power too is called into question. An alternative logic of governmentality is posed by Achille Mbembe, who argues that in such cases, sovereign power is not just about the regulation of life but it is also the power over death, the systematic destruction of people and the subjugation of life to death, as 'the living dead'. ${ }^{40}$ Central to Mbembe's theorisation is consideration of the following question: 'Under what practical conditions is the right to kill, to allow to live, or to expose to death exercised?'41 This approach, referred to as necropolitics, builds on similar foundations to Agamben, taking it a step further to exert the power to control those who live and die.

The increasing prominence of work by scholars such as Agamben and Mbembe within international relations has stimulated a vibrant debate over the application of such ideas to the contemporary world. ${ }^{42}$ One of the main points of tension in Agamben's work is concerned with his understanding of biopolitics, which builds upon Foucault's engagement with the term, seeking to 'correct' a number of factors, notably the idea that the rise of biopower heralded the emergence of modernity. ${ }^{43}$ Instead, Agamben argues that politics is always biopolitical, as the political is shaped by the state of exception and its production of bare life. Another point of contention concerns the lack of development of this monolithic construction of bare life, ${ }^{44}$ which can differ depending upon context and conditions. Nor does Agamben differentiate between liberal democratic regimes and totalitarian regimes; rather, he suggests that 
it is the division between bios and zoe that is the most important characteristic of political life. ${ }^{45}$

Perhaps the most damning criticism of Agamben's work concerns the role of agency and scope for resistance against structural conditions. ${ }^{46}$ It is clear that structural factors are central to discussions of sovereignty and that agency operates within the confines of structural parameters. Yet Agamben's approach is guilty of restricting agency, removing socio-economic contexts that are essential for understanding the contingency and relativity of different situations. Even within restrictive conditions, individuals have the capacity to exercise agency, no matter how remote the possibility; and as a number of scholars note, even the refugee can exercise agency. ${ }^{47}$ From this, amid the increasingly restrictive conditions of authoritarian rule, we can still speak of agency and the exception.

Agamben responds to this criticism by suggesting that agency is reasserted by taking ownership of the condition, as 'putting life into play. ${ }^{48}$ To claim ownership, one has to accept the conditions of 'being thus' and to acknowledge the conditions within which one exists. Even this lacks methodological development, failing to adequately explore the impact of agency upon structures, as agency also operates prior to being and both prior to and post restructuring. Returning agency to the discussion allows for a greater analysis of political activity and consideration of structural changes within society.

Agamben speaks of the destruction of identities (and agency) through desubjectivation and resubjectivation, the reshaping of destroyed identities. If individuals exercise agency then this is a resubjectivation of the self. In Agamben's work, sovereignty is fully constituted as the only conceptual space within which the logic of sovereignty is sound but this concept merges potentiality and being, where potentiality can only be viewed retroactively. ${ }^{49}$ Slavoj Žižek's response to this is to suggest that there must be an act prior to being, 'overlooking the fact that the order of being is never simply given, but is itself grounded in some preceding Act. ${ }^{50}$ By accepting Žižek's point, we take sovereignty as a process that is ongoing in order to maintain logical consistency and by focusing upon the act, we are able to return agency to our project, albeit shaped by context and contingency.

In The Use of Bodies, Agamben engages with ontology and potentiality to suggest that sovereignty should be a process, an act that repeats itself, which supports both the need to do this and the scope for us to do so. With that in mind, the process of sovereignty is ongoing, continually regulating life, yet amid the fragmentation of political organisation, this regulation evolves into the subjugation of life to death. Ultimately, what remains central are regime struggles to retain power and exert sovereignty, using a range of different logics of governmentality. When it is contested, the mere regulation of life through the ban and exception suffice, yet when this contestation escalates, the regulation of life turns to subjugation of death. While sovereign projects are typically associated with territorial spaces that are central to the Westphalian state, amid fragmentation and contestation the parameters of space become disputed. As Mbembe suggests, space is 'the raw material of sovereignty and the violence it carried with it. ${ }^{51}$ 
The fragmentation of sovereignty can result in existential transformation as life is displaced, often stripped of political meaning and reduced to bare life. It is within such conditions that we see the emergence of war machines, entities that challenge the rule-based form of political organisation. Developed by Gilles Deleuze and Felix Guattari, the concept of the war machine sits in opposition to the state, which exists as an apparatus of power distinct from societies. Seeking to reject the power of the state, particularly amid conditions of fragmentation, Deleuze and Guattari suggest that a new form of war emerges, akin to that conducted by nomads. The analogy used to denote this is between a game of chess and Go where the former codes and decodes space while the latter seeks to territorialise or deterritorialise. ${ }^{52}$

This form of war is often in tension with state apparatus but is also counterhegemonic, applying as much to intellectual debate as to conflict. ${ }^{53}$ War machines exist as the manifestation of disruption, operating against states, but also with the possibility of being incorporated into state structures. Within sites and spaces of exception, power is 'contracted' out, functioning as private organisations one stage removed from the state. The idea of the war machine evokes memories of a Hobbesian 'war of all against all' following the descent into the state of nature, particularly amid the fragmentation of political organisation.

The goal of the war machine is to bring everything back to the 'empty space' of what is seen as the primordial tabula rasa. As Deleuze and Guattari suggest, the war machine is 'a pure form of exteriority, whereas the State apparatus constitutes the form of interiority', the means through which space is coded and decoded: 'It is the State that makes possible the distinction between governors and governed. ${ }^{54}$ Fundamentally, 'the concern of the State is to conserve ${ }^{55}$ while the war machine aims to deterritorialise, seen in the nomad who challenges 'the rules and structures of the sedentarised form of political life, existing as a fundamental challenge to states, for whom a vital concern is to vanquish nomadism' and to 'establish a zone of rights over an entire "exterior" . ${ }_{56}$

Operating through interaction with the state, the war machine challenges the ordering of space. The unappropriated war machine

has as its object not war but the drawing of a creative line of flight, the composition of smooth space and of the movement of people in that space. At this other pole, the machine does indeed encounter war, but as its supplementary or synthetic object, now directed against the State and against the worldwide axiomatic expressed by the States. ${ }^{57}$

The manifestation of a war machine is irreducible to the state apparatus although, as we shall see, it may be appropriated by states, wherein previously autonomous social movements are harnessed by a regime, losing their deterritorialised essence in the process and embracing purposeless destruction. ${ }^{58}$ It is beyond the scope of our project to go into these concepts in more detail, but the idea of war machines offers a conceptual tool to discuss mobilisation against state power - as a manifestation of exterior against interior - which, as we shall see in later chapters, plays a prominent role in times of contestation. 


\section{Space and nomos}

While politics is inherently about people, space is the theatre within which interactions take place. It is simultaneously a physical environment, a semiotic abstraction, and relational. ${ }^{59}$ These interactions exist within one another and coexist within power relations and social practices. Each society produces a space of its own nature along with a set of rules that regulate behaviour within space. The concept of space is deeply contested among scholars yet is central to understanding contemporary political organisation, from the camp to the city to the state. Each different definition contains within it sets of interactions and struggles for domination, which are context specific and shaped by a range of different contingent factors. Such a position bears the hallmarks of the work of Doreen Massey, who in For Space sets out three propositions that are central to our project. First, space is the product of a set of interactions and struggles that range from the 'intimately tiny' to the global. Second, space should be viewed as a sphere of possibility, heterogeneity and multiplicity. Third, that space is in a constant state of construction. ${ }^{60}$ Through these interactions, what happens in one space can have implications for other spaces, transcending both political and normative environments.

The establishment of boundaries is fundamentally an attempt to stabilise meaning within space and time, although such efforts are sites of contestation, 'battles of the power to label space-time, to impose the meaning to be attributed to space. ${ }^{61}$ They are sites of contestation, arenas within which power is exerted. ${ }^{62}$ Yet such things are not truly bounded, but rather in flux, ongoing processes of movement and evolution; social and dynamic, with scope for reproduction and transformation..$^{63}$ People operate and exist within such spaces, regulated by power relations and given meaning amid contestation and the definition of community by articulating an outside against which one is closed off, although amid fluid boundaries this closure is increasingly problematic. Although regimes and states are the actors that predominantly regulate space, they are not alone. When meaning is rejected it becomes contested amid efforts to (re)appropriate space. In doing this, rights become asserted through the performance of a new spatiality by contesting the regulatory mechanisms - the governmentality - of such spaces.

Agamben's Homo Sacer project is one that engages with profoundly spatial questions. Central to discussions of space and political life is nomos, a foundational ancient Greek concept used to denote 'a range or province, within which defined powers may be legitimately exercised. ${ }^{64}$ Nomos is subject of a range of (often competing) interpretations that facilitate the interrogation of order, life and existence. ${ }^{65}$ Agamben's reading of nomos is influenced by Schmitt, whose treatise The Nomos of the Earth set out a view of world order that roots law to land, stressing fundamentally spatial characteristics through the interaction of ortung (localisation) and ordnung (ordering). ${ }^{66}$ Schmitt's understanding of nomos views it as 'the original spatial order, the source of all further concrete order and further law. It is the reproductive root in the normative order of history ${ }^{3}{ }^{67}$

Schmitt's ideas come out of the end of the Second World War and are underpinned by his views on the political and a fundamental concern with order. In his view, politics was the 'art of ordering' (emphasis in original), the localisation and ordering of 
space. ${ }^{68}$ This, for geographers such as Claudio Minca and Rory Rowan, demonstrates Schmitt's spatial turn, as such events take place within space, but also shape space. In this view, land appropriation was the foundational act of existence, resulting in the belief that the nomos was a fundamentally ontological act, an original spatialisation. ${ }^{69}$ Schmitt's work suggests that nomos is a consequence of the interaction between ordnung and ortung, between space and ordering and while this interaction is important, it suffers through Schmitt's failure to acknowledge both the importance of agency and norms. Indeed, as John Agnew argues, the very idea of the state as the manifestation of political organisation requires drawing upon shared histories and cultural legacies in an attempt to create order within space. ${ }^{70}$

In contrast, for Agamben, nomos is the localisation of the unlocalisable, the immediate form through which Schmitt's axiom that 'the political and social order of a people becomes spatially visible' rings true. ${ }^{71}$ Concepts of polis and nomos are thus fundamentally interrelated, shaped by spatial concerns. As Deleuze and Guattari argue,

[T] he State itself has always been in a relation with an outside, and is inconceivable independent of that relationship. The law of the State is not the law of All or Nothing (State-societies or counter-State societies), but that of interior and exterior. The State is sovereignty. But sovereignty only reigns over what it is capable of internalizing, of appropriating locally. ${ }^{72}$

Building on Schmitt, Agamben adds the nation as an additional dimension of discussions about the nomos, ${ }^{73}$ suggesting that the global nomos is a product of neoliberal modernity, the spatial manifestation of the unlocalisable exception. Yet within this global nomos are individual spatial orderings - nomoi - characterised by the global nomos yet given meaning by the context and contingency of space and local agency. ${ }^{74}$ Countless identities, ideologies and beliefs exist often with competing views of political organisation, emerging in the relationships that people have to the governance structures of the state and the way in which people live their lives. Such a view means that although existing within a global nomos, there are other nomoiwith spatial characteristics - that order communities; it is the spatial characteristic that differentiates nomos and nomoi from norms. The manifestation of sovereign power is contingent on the organisation of such spaces - particularly in the postcolonial world - brought to life by Schmitt's ideas about the interaction between ordnung and ortung. This position suggests that we must not only focus more on the normative aspect of nomos but also engage with questions about the very concept of community.

Communities are central not only to discussions of nomos but also to the very nature of political organisation. As Hans Lindahl argues, 'no political community is imaginable ... that does not close itself off as an inside over against an outside. Moreover, and no less importantly, by closing itself off as an inside with respect to an outside, a community posits a space as its own. ${ }^{75}$ Here, not only does the closing off define the metaphysical aspects of a community and with it, the rules that regulate it, but also the space that a community resides in. Such a definition is not fixed, however, but is predicated upon ongoing subjective interactions that establish principles and 
institutions. ${ }^{76}$ Moreover, in closing off space against an outside, the possibility of citizenship is conditioned through membership of a shared community.

For Hannah Arendt, 'all legislation creates first of all a space in which it is valid, and this place is the world in which can move in freedom. What lies outside this space is lawless and properly speaking without a world. ${ }^{77}$ In On Revolution, the importance of spatially bounded territory for the establishment of a political community and the rules that regulate life are acknowledged. ${ }^{78}$ Here, however, we can see parallels with the work of Khaldun, who makes similar claims about the importance of boundaries and the normative ordering of space:

[1] The world is a garden the fence of which is the dynasty. [2] The dynasty is an authority through which life is given to proper behaviour. [3] Proper behaviour is a policy directed by the ruler. [4] The ruler is an institution supported by the soldiers. [5] The soldiers are helpers who are maintained by money. [6] Money is sustenance brought together by subjects. [7] The subjects are servants who are protected by justice. [8] Justice is something familiar, and through it the world persists. The world is a garden. ${ }^{79}$

This approach evokes ideas of the need for a reflexive reading of nomos of the sort advocated by Hans Lindahl, stressing the ongoing relationship of ordnung and ortung and between nomos and nomoi. This dialectic relationship has occupied a central role in the establishment and evolution of political projects across the past century.

Building on this and the notion that the closure of space conditions the possibility of citizenship, Arendt argues that the world gains meaning through the interaction of people, their words and deeds. ${ }^{80}$ This world building is an essential part of the closure of an inside against an outside, stressing the importance of the normative within nomos and political community. Put another way, as Robert Cover argues, 'to inhabit a nomos is to know how to live in it. ${ }^{81}$ Knowing how to live requires awareness of both the formal and normative structures that can regulate life: the political, legal and economic structures that are designed and implemented by regimes, along with the normative structures that can be harnessed by both regimes and communities for a range of ends. In harnessing the normative, myths, narratives and histories can be moulded and put to use in 'meaningful patterns' to regulate behaviour and can be passed across generations, learned, developed and moulded.

Yet as Cover acknowledges, the establishment of such a nomos brings with it its own unavoidable demise, amid debate around interpretation, creed, identity and practice. Thus, a fleeting instant of emergence as objective meaning creates a template for 'a thousand real integrations. ${ }^{82}$ Take, for example, faith and membership of a religious community. Beyond that immediate moment of shared belief, a plurality of interpretations exist that differ in practice, leading to contestation and a struggle to regulate political life and meaning. For Cover,

Legal precepts and principles are not only demands made upon us by society, the people, the sovereign, or God. They are also signs by which each of us 
communicates with others. There is a difference between sleeping late on Sunday and refusing the sacraments, between having a snack and desecrating the fast of Yom Kippur, between banking a check and refusing to pay your income tax. In each case an act signifies something new and powerful when we understand that the act is in reference to a norm. It is this characteristic of certain lawbreaking that gives rise to special claims for civil disobedients. But the capacity of law to imbue action with significance is not limited to resistance or disobedience. Law is a resource in signification that enables us to submit, rejoice, struggle, pervert, mock, disgrace humiliate, or dignify. ${ }^{83}$

Similar arguments can be made about Islam and interpretations of Quran, Sunna and hadith. While some claims are fundamental - such as tawahid, the oneness of God - transgression is also justified within the Quran, leading to numerous possible interpretations. ${ }^{84}$

Of course, different contexts and their socio-economic, historical, cultural contingencies only serve to facilitate transgression and diffusion; for example, a Muslim in the UK has a different set of experiences and context-specific practices to a Muslim in Indonesia, while a Muslim in Israel has a different way of life to a Muslim in Oman. At a more micro level, a Sunni Muslim in Saudi Arabia will have a different set of beliefs, practices and experiences to a Shi'a Muslim from the same state. The nomos then becomes the arena for the interaction of a set of normative structures predicated upon a shared belief and fleeting moment of unity, resulting in a process of tension and reconciliation that plays out in the community. From this we can see how ideas easily transcend the territorially grounded polis, leading to challenges to the sovereign state, the global nomos and competing interpretations of ordnung and ortung, although this challenges the idea of a political community as closed off as an inside against an outside, contesting sovereign power in the process.

Yet when considering how different communities emerge that seek to close themselves off as an inside against an outside, tensions arise between different visions of the inside and the extent to which normative ordering finds traction in space. Such an extension can be applied to the building of collective identities, although tensions can emerge when state formation clashes with tribal or religious loyalties. Here, much like Sophocles' Antigone, individuals may find themselves caught between the law of the state and the normative values that regulate life. ${ }^{85}$ Moreover, when groups seek to close themselves off against an outside within the inside, political projects face existential challenges. Here, competing visions of the ordering of space emerge from within, stemming either from the transient nature of nomos or from competing efforts to order space. This problem was identified historically by Khaldun who stressed the importance of asabiyyah as a form of collective membership, transcending the loyalty to family and group. ${ }^{86}$ Of course, amid contestation and fragmentation, asabiyyah breeds asabiyyah as family, tribe and group become pitted against each other.

Yet Arendt's words can be applied on a grander scale: 'the organisation of the people as it arises out of acting and speaking together, and its true space lies between people living together for this purpose, no matter where they happen to be ... can find its 
proper location almost anytime and anywhere. ${ }^{87}$ Rather than people directly living together, it can be applied to people living according to the same rules regardless of the spatial location and the contingent factors that shape those rules. The concept of nomos helps us to understand membership of this type of community, not necessarily territorially grounded, but underpinned by a set of normative beliefs that regulates life and shapes political behaviour, closing off a metaphysical inside against an outside with implications for the spatialised nomos. ${ }^{88}$

A final observation must be made about the impact of closing off an inside against an outside on the construction of citizenship and the ordering of space. Fundamentally, nomos cannot include without excluding and while this predominantly takes place against other communities, it can also concern individuals who are displaced from the inside. While citizenship is the manifestation of inclusion, statelessness is the dominant form of displacement, facilitated by racial undertones.$^{89}$ There is no form of self-inclusion without a measure of self-exclusion..$^{90}$ Here we see how sovereign power can operate and order space, giving life meaning through inclusion within the political life of a community, but also stripping it of this meaning through a form of exclusion.

As we shall see in the coming chapters, nomos is shaped by local context and contingency, which in the Middle East results in challenges to the spatial and ordering aspects of the regulation of life. Authority can be claimed by various individuals and groups, including family hierarchies, tribal leaders, religious officials, regional officers, employers and rulers but when applied to the sovereign state, it is assumed that these forms of authority have coalesced into a hierarchical structure within a particular territory. Across the Middle East, regime authority - and autonomy - can be challenged by actors operating both at a sub-state and supra-state level who are often able to lay more convincing claims to authority, legitimacy or power. With a rich normative environment serving as a means of legitimising rule that does not directly correspond with the geographic spaces of the sovereign state, what happens in domestic spaces can - and does - have regional consequences.

A further challenge emerges where regimes are unable to compete with strong societies in what Joel Migdal termed a struggle between strong societies and weak states. ${ }^{91}$ Weak states are those who are unable to enforce governance structures, to 'penetrate society, regulate social relationships, extract resources, and appropriate or use resources in determined ways' (emphasis added), where social forces stymie efforts at exerting authority. ${ }^{92}$ It should be noted that structures that regulate authority can be both formal and normative - including but not limited to political, legal, economic, normative and religious - stemming from a range of sources. Essentially, the crux of Migdal's claim is that states and societies compete for social control, practices and norms, influencing each other in the process.

As Marisela Montenegro and Joan Pujol suggest, contemporary manifestations of governmentality resort to different logics of sovereignty in an attempt to maintain power and order. For Montenegro and Pujol, this modern governmentality

combines biopolitical and necropolitical logics to establish social, political and physical borders that classify and stratify populations using symbolic and material 
marks ... The safeguarding of worthy populations is enacted and justified by pointing to potentially threatening events and declaring 'state of exception. ${ }^{\text {' }}$

Thus, we can see how sovereign and governmental logics set out by Agamben and Mbembe can be taken alongside one another, contingent on the intricacies of time and space. Underpinning these approaches, however, is the cultivation of an other, a racism that in Mbembe's words, can 'regulate the distribution of death and to make possible the murderous functions of the state. ${ }^{94} \mathrm{~A}$ direct consequence of this is the creation of new forms of subjugation.

\section{Sovereignty, space and nomos in the Middle East}

The history of political organisation across the Middle East is one of contestation. Efforts to maintain control amid an array of competing pressures from various locations reveals a range of different logics of governmentality that are key to ensuring survival. Interrogating these techniques and strategies helps to understand the contemporary Middle East and, ultimately, instances of violence and revolution such as those seen in 2011. From the regulation of life to the subjugation of life to death, a range of mechanisms of governance and governmentality exist to provide regimes with the ability to exert power, albeit not without contestation, as competing groups seek influence through laying claim to social norms, practices, economies and claims to sovereignty, with spatial consequences.

The interaction of these factors and the closing of an inside off against an outside show how people can become marginalised from political communities and exist within bare life, reintroduced into yet excluded from politics through the declaration of a state of exception. Within this context, political life was stripped from large numbers of people across the Middle East, where lives became expendable as government machinery attempted to retain control. Such processes are ongoing as regimes seek to maintain power and people engage with the structures of politics. Following decades of exception and bare life, the Arab Uprisings became an outlet for much of the frustration people had with governance structures regulating life, resulting in a struggle between regimes and societies and the (further) marginalisation of particular identities for domestic, regional and international audiences.

Put another way, the state of exception begot the state of exception, while bare life begot bare life. As noted in The Kingdom and The Glory, to understand politics - and the Arab Uprisings - it is imperative to look at government and governance structures within a state that serve the biopolitical project. The need to do this is supported by the 2016 Arab Human Development Report, which argues that 'the events of 2011 and their ramifications are the outcome of public policies over many decades that gradually led to the exclusion of large sectors of the population from economic, political and social life. ${ }^{95}$

Nomoi are not limited to the nation-state but can exist across space. The pan-Arab movement with Gamal Abdl Nasser at its vanguard suggested that the Arab states were 
subservient to a larger collective, to umma arabiyya wahida dhat risala khalida, the one Arab nation with an immortal mission.96 This vision eviscerated states and societies and eroded their agency, claiming to speak for the vox populus, leaving the nation state in its wake. Rulers aware of the power of this narrative would tap into a source of legitimacy that transcended domestic reserves, despite its threat to the survival of the sovereign state and used its symbolic power in an effort to engender popular support. ${ }^{97}$

The birth of pan-Islamism stemmed from a desire to challenge the pan-Arab discourse and Saudi Arabia's attempt to counter the rising power of Nasser's Egypt by stressing the importance of Islamic unity, ${ }^{98}$ along with the proselytising of a Wahhabist vision brought about through the development of the Islamic University of Medina and provision of training and funding to Imams from across the world. ${ }^{99}$ A pure panIslamist vision also held Middle East states to be transient entities working towards the unification of the Muslim world, yet much like Arabism before it, the ideology was increasingly used for political ends, leading to political rivalry between states, with domestic and regional repercussions. ${ }^{100}$ Ultimately, both ideological movements were brought down by the enduring power of the nation-state, ${ }^{101}$ yet the nature of global political life means that the state once more appears to be contested and the legacy of these movements remains.

Such movements also challenged the spatial aspects of the sovereign state that had come to dominate the international system, a site of contestation between regimes and broader populist movements that derived legitimacy from a greater, collective movement not confined to the borders of the sovereign state. Both pan-Arabism and pan-Islamism appealed to a sense of asabiyyah among the people of the region, drawing upon shared normative views - albeit in a number of different forms - in an attempt to construct a broad community of support against an outside, which were traditionally colonial agendas and the establishment of Israel. In recent years, this 'outside' has been constructed as Shi'a and Persian.

Yet the instrumentalised use of such narratives was not without problems, as Michael Barnett reveals in Dialogues in Arab Politics. ${ }^{102}$ Such ideologies also provided domestic support against the Communists and Leftist movements as regimes across the Gulf sought to empower groups such as the Muslim Brotherhood to counter the perceived threat posed by Communism. Longer term, regimes implemented structures that sought to restrict the possibility of agency, while holding together the fabric of political organisation. State-building processes seek to circumvent these challenges and establish a framework ensuring regime security and stability while the existence of structures to circumvent challenges results in a range of different structural pressures across states, which resulted in violence in times of severe contestation. Moreover, the location of states within shared normative environments means that events in one state can reverberate across the region, having an impact upon the domestic affairs of others.

Amid a range of challenges including but not limited to Western military engagement, global financial crises, a growing middle class ${ }^{103}$ and huge demographic changes, notably a youth boom and a population increase of 53\% between 1991 and 2010, along with waves of urbanisation, ${ }^{104}$ social contracts and ruling pacts began to fragment. Before the uprisings, middle classes were largely stable, albeit subjected to a range of governance 
strategies, yet political marginalisation and the rising price of essentials - especially bread - altered this stability. A Human Development Report that tracked change between 2009 and 2014 offers greater insight into events at this time, noting a positive change of +10 in Saudi Arabia, facilitated by the $\$ 96$ billion package of social reform, and a negative change of -15 in Syria. ${ }^{105}$ With the emergence of states of exception across the region, perhaps best characterised in Egypt's Emergency Laws, people were marginalised by legal and political structures and political meaning was stripped from life. From this, in order to understand the uprisings, we must identify both the conditions and the structures that facilitated the biopolitical project and ultimately, bare life.

As the uprisings continued across the region, revolution and counter-revolution vied for control. In Egypt, the end of the Mubrak era resulted in a democratically elected Muslim Brotherhood regime under the leadership of Mohammad Morsi, which also stressed the need for emergency legislation to maintain security and stability. ${ }^{106}$ The counter-revolution that toppled Morsi violently banned the group's supporters from political life in Egypt, imprisoning thousands of Muslim Brothers and their followers, along with the massacre of over a thousand of the group's supporters on 14 August 2013 in Cairo. Those states who had supported the Morsi presidency were subjected to geopolitical punishment, as a Saudi-led bloc sought to regulate life not only within their states but also across the Middle East.

The fragmentation of states and their structures resulted in the erosion of sovereignty, necropolitics, war machines and conditions of bare life across the region. Amid such conditions, the emergence of social movements - war machines - that challenged the power of the state was hardly surprising. During times of conflict across the region, war machines have emerged as a means of contesting the power of the state, albeit occasionally co-opted into those structures. In some cases, this resulted in the erosion of political projects driven by irredentist and secessionist movements. As Ariel Ahram notes, much of the focus on political projects in the Arab world presumes the state to be 'immutable and fixed', albeit 'fierce but weak', ${ }^{107}$ yet amid contestation and fragmentation to hold such a position is infelicitous. Such a position is especially troubling when faced with secessionist and irredentist movements in Syria, Iraq, Iran, Turkey and Yemen. From numerous forms of competition to sovereign power, a plethora of possible outcomes emerge, contingent upon time and space, requiring analysis of the relationship between rulers and ruled.

Within the context of fragmenting sovereignty that left states vulnerable to the political ambitions of others, regimes manipulated events to ensure their own survival. Islamic rhetoric was increasingly used as a cloak for geopolitical agendas, best seen through Iranian and Saudi Arabian efforts to increase the legitimacy and vitality of their own rule for internal and external audiences. ${ }^{108}$ Schisms within the Muslim world also served as a means of undermining governmentality, authority and autonomy, as individuals faced often-contradictory guidance from competing sources of authority. Religious difference led to securitised divisions while also proving to be a useful tool in efforts to retain security after the Arab Uprisings. 


\section{Conclusions}

Questions about sovereign power remain central to understanding the nature of political organisations. To understand political life, one must understand the manifestation and contestation of sovereign power. Within such projects, the role of the state occupies a central role, albeit one that is increasingly contested within a global nomos that is defined by spatial exception and underpinned by neo-liberal modernity. Within this nomos, the localised unlocalisable becomes contested as context and contingency challenge the relationship between ordnung and ortung, with serious consequences for sovereign projects and the organisation of communities. ${ }^{109}$ The process of defining an inside against an outside is central to the establishment of communities that then regulate life according to their normative codes. Yet competing visions of how to live and the values that structure such visions do not always coalesce with state sovereignty, resulting in challenges to the sovereign order.

Although deploying a number of theoretical positions in pursuit of answers, these approaches fit together neatly, sharing similar ontological foundations. Consideration of sovereign power allows for a greater focus on agency and human action. Fundamentally concerned with the regulation of life, sovereignty seeks to ensure regime survival through the removal of political meaning from life and creating conditions of bare life, or by controlling life by subjugating it to death. In opposition to regime power, war machines emerge that contest the organisation of political life. These interactions all take place within space, bringing together regional dynamics with intimately small local dynamics. Understanding the ordering of space goes some way in understanding political action and here nomos helps to understand the regulation of political organisation. Taken together, we have a rich tapestry that allows us to understand the manifestation of sovereign power, the areas in which such power is exerted and the means through which it is contested.

In spite of ongoing contestation, the state remains the central focus of our exploration, albeit in many forms. What we shall see, however, is that amid a fundamental struggle to exert sovereign power through the regulation of life, the repercussions are felt across space and time. In the contemporary world, these repercussions of political action are felt beyond state borders, while the harnessing of competing sovereignties locates political struggles within broader geopolitical and normative environments. While the state is often taken as a distinct unit, closer examination leaves it comprised of a number of different factors, existing across different spaces, shaped by the interactions that construct space.

The sovereign state is inherently an exclusionary concept and the need to define, redefine and maintain the exception exposes the power of the state. To understand political spaces, we must consider not only the relationship between rulers and ruled - and thus included and excluded - but also technologies of exclusion, which are (re)negotiated in response to context-specific contingent factors. Although we are concerned with the contestation that occurs within the state, tensions between loyalty to the state and to the nomos means that we have to locate our exploration within 
spatial dynamics across the Middle East, replete with contestation. As our journey continues, we must locate the state - and its discontents - within broader geopolitical and normative environments. By doing this we are better placed to engage with the regulation of life and the subjugation of life to death.

\section{Notes}

1 This chapter is a modified version of an article originally published in Third World Quarterly. I thank the editors for permission to reuse it here.

2 Ibn Khaldun, The Muqaddimah: An Introduction to History (Franz Rosenthal trans.) (Princeton, NJ: Princeton University Press, 1967), p. 39.

3 Charles Tilly, The Formation of Nation States in Western Europe (Princeton, NJ: Princeton University Press, 1975), p. 45.

4 Ghassan Salame, Introduction, in Ghassan Salame (ed.), The Foundations of the Arab State (Oxford: Routledge, 1987), p. 3.

5 See, among others, Talal Asad, 'Where Are the Margins of the State?', in Veena Das and Deborah Poole (eds), Anthropology in the Margins of the State (Santa Fe, NM: School of American Research Press, 2004), pp. 279-88; Nazih N. Aubui, OverStating the Arab State (London: I. B. Tauris, 1995); Roger Owen, Rise and Fall of Arab Presidents for Life (Cambridge, MA: Harvard University Press, 2012); Roger Owen, State, Power and Politics in the Making of the Modern Middle East (Oxford: Routledge, 2004); Lisa Anderson, 'The State in the Middle East and North Africa', Comparative Politics, 20:1 (1987): 1-18; Charles Tripp, 'The State as an Always-Unfinished Performance: Improvisation and Performativity in the Face of Crisis', International Journal of Middle East Studies, 50 (2018), 337-42; Fred Halliday, The Middle East in International Relations: Power, Politics and Ideology (Cambridge, UK: Cambridge University Press, 2005); Philip S. Khoury and Joseph Kostiner (eds), Tribes and State Formation in the Middle East (Berkeley: University of California Press, 1990); Fouad Ajami, The Arab Predicament: Arab Political Thought and Practice since 1967 (Cambridge, UK: Cambridge University Press, 1992); Joel Migdal, Strong Societies and Weak States (Princeton, NJ: Princeton University Press, 1988).

6 Migdal, Strong Societies and Weak States, p. 19.

7 Tilly, The Formation of National States, p. 42.

8 Rolf Schwarz, War and State Building in the Middle East (Gainesville, FL: University of Florida Press, 2012), p. 18.

9 Lisa Anderson, 'The State in the Middle East and North Africa', p. 74.

10 Yahya Sadowski, Scuds or Butter? The Political Economy of Arms Control in the Middle East (Washington, DC: Brookings, 1993). The idea of the rentier state was a prominent feature of early work on the contemporary Middle East, driven by the ideas of Beblawi and Luciani in particular. See Hazem Beblawi, 'The Rentier State in the Arab World, in Giacomo Luciani (ed.), The Arab State (London: Routledge, 1990), pp. 85-98; and Giacomo Luciani, 'Allocation vs Production States: A Theoretical Framework', in Giacomo Luciani (ed.), The Arab State (London: Routledge, 1990), pp. 65-84.

11 Russell E. Lucas, 'Monarchical Authoritarianism: Survival and Political Liberalization in a Middle Eastern Regime Type', International Journal of Middle East Studies, 36 (2004), 106. 
12 Robert M. Fishman, 'Rethinking State and Regime: Southern Europe's Transition to Democracy', World Politics, 42:3 (1990), 428.

13 Albert Hourani, 'How Should We Write the History of the Middle East?', International Journal of Middle East Studies, 23 (1991), 125-36.

14 Asad, 'Where Are the Margins of the State?', p. 281.

15 Lisa Anderson, 'Essential Readings: The Arab State' (Middle East Pedagogy Initiative, 19.06.18), available at www.jadaliyya.com/Details/37665/Essential-Readings-TheArab-State (accessed 19.07.18).

16 See Michael Barnett, Dialogues in Arab Politics: Negotiations in Regional Order (New York: Columbia, 1998); and Malcolm Kerr, The Arab Cold War: Gamel 'Abd Al-Nasir and His Rivals, 1958-70 (Oxford: Oxford University Press, 1972).

17 Toby Dodge, " "Bordieu Goes to Baghdad": Explaining Hybrid Political Identities in Iraq', Journal of Historical Sociology, 31 (2018), 25-38.

18 Taken to be the worldwide community of Muslims.

19 B'Tselem, an Israeli human rights organisation, puts this number at 547,000 people living in 125 government-sanctioned settlements in the West Bank and a further 100 settlement outposts. See B'Tselem, Statistics on Settlements and Settler Population (Jerusalem: Israeli Information Center for Human Rights in the Occupied Territories, n.d.). The designation of Areas A, B and C was an attempt to facilitate the Israeli military withdrawal from the West Bank and the transfer to the Palestinian Authority as part of the peace process. According to Dror Etkes, an anti-settlement activist, 'the takeover of land in Area B is a combination of unbridled thievery by settlers and impotence on the part of the Israeli authorities'.

20 Fred Halliday, 'The Middle East and the Politics of Differential Integration', in Toby Dodge and Richard Higgot (eds), Globalisation and the Middle East: Islam, Economics Culture and Politics (London and Washington, DC: Royal Institute of International Affairs and Brookings Institution Press, 2002); and Raymond Hinnebusch, 'The Middle East in the World Hierarchy: Imperialism and Resistance', Journal of International Relations and Development, 14:2 (2011), 232.

21 Although a number of academic outlets have begun to contest colonial history. A number of years ago, an article of mine was rejected by a prominent international relations journal on the grounds that 'the Middle East had no colonial legacy'.

22 See Simon Bromley, American Hegemony and World Oil: The Industry, the State System and the World Economy (University Park, PA: Penn State University Press, 1991); and A. Alnasrawi, Arab Nationalism, Oil and the Political Economy of Dependency (New York: Greenwood Press, 1991).

23 See Simon Bromley, Rethinking Middle East politics (Austin, TX: University of Texas Press, 1994).

24 Steven Krasner, 'Compromising Westphalia', International Security, 20:3 (1995-96), 116.

25 Carl Schmitt, Political Theology. Four Chapters on the Concept of Sovereignty. (Chicago: University of Chicago Press, 2005).

26 Giorgio Agamben, State of Exception (Chicago: Chicago University Press, 2005), p. 33.

27 Giorgio Agamben, Homo Sacer, Sovereign Power and Bare Life (Stanford, CA: Stanford University Press, 1995), p. 18.

28 Agamben, State of Exception, p. 3.

29 Ibid., p. 23.

30 Ibid., p. 9. 
31 Ibid., p. 123.

32 Ibid., p. 169.

33 Bulent Dilken, 'Zones of Indistinction: Security, Terror and Bare Life', in Anselm Franke and Kunst-Werke Berlin (eds), Territories: Islands, Camps, and Other States of Utopia (Berlin: Verlag der Buchhandlung Walther König, 2003), pp. 42-51. A similar point is made by J. Edkins and V. Pin-Fat, 'Introduction: Life, Power, Resistance,' in J. Edkins, M. J. Shapiro and V. Pin-Fat, Sovereign Lives: Power in Global Politics (New York: Routledge, 2004), p. 9.

34 Derek Gregory The Colonial Present: Afghanistan, Palestine, Iraq (Oxford: Blackwell, 2004), p. 258.

35 Giorgio Agamben, The Kingdom and the Glory, Palo Alto, CA: Stanford University Press, 2011), p. 276.

36 Giorgio Agamben, The Use of Bodies (Palo Alto, CA: Stanford University Press, 2016).

37 Wael Hallaq, The Impossible State (New York: Columbia University Press, 2013), p. 29.

38 Hourani, 'How should we write'.

39 An obvious criticism emerges when considering the application of a Western theory to the Middle East. Initially, such an attempt may fall foul of intellectual neo-colonialism and essentialism, yet when looking at the work of Wael Hallaq, particularly in The Impossible State, one can make the case that the metaphysics of states in the region share a number of characteristics with states across the world.

40 Achille Mbembe, 'Necropolitics', Public Culture, 15:1 (2003), 11-40.

41 Ibid., p. 12.

42 See Angharad Closs Stephens and Nick Vaughan-Williams (eds) Terrorism and the Politics of Response (Oxford: Routledge, 2009); Edkins et al., Sovereign Lives; Sergei Prozorov, 'Three Theses on "Governance" and the Political', Journal of International Relations and Development, 7:3 (2004), 267-93.

43 For purposes of brevity, the debate about the validity of Agamben's claims will be left to other scholars. For an introduction, see Patricia Owens, 'Reclaiming "Bare Life”?: Against Agamben on Refugees', in International Relations, 23:4 (2009), 567-82.

44 C. Levy, 'Refugees, Europe, Camps/State of Exception: “Into the Zone”: The European Union and extraterritorial Processing of Migrants, Refugees, and Asylum-Seekers (Theories and Practice)', Refugee Survey Quarterly, 29:1 (2005), 26-59.

45 Thomas Lemke, “A Zone of Indistinction”: Critique of Giorgio Agamben's Concept of Biopolitics', Outlines: Critical Practice Studies, 7:1 (2005), 8.

46 William Walters, 'Acts of Demonstration: Mapping the Territory of (Non-) Citizenship', in E. Isin and G. Neilson (eds), Acts of Citizenship (London: Zed Books, 2008), pp. 182-207.

47 Dan Bousfield, The Logic of Sovereignty and the Agency of the Refugee: Recovering the Political from 'Bare Life' (YCISS Workling Paper Number 36, October 2005); and Owens, 'Reclaiming "Bare Life"?.

48 Agamben, Profanations (New York: Zone Books, 2007).

49 Agamben, Homo Sacer, p. 45.

50 Žižek, The Ticklish Subject The Absent Centre of Political Ontology (New York: Verso, 1999), p. 238.

51 Mbembe, 'Necropolitics', p. 26.

52 Gilles Deleuze and Felix Guattari, Nomadology: The War Machine (South Pasadena, CA: Semiotext(e), 1986). 
53 Although the name suggests otherwise, the war machine need not necessarily be violent, but rather something that contests the formal power of the state.

54 Deleuze and Guattari, Nomadology, p. 13.

55 Ibid.

56 Ibid., p. 59.

57 Gilles Deleuze and Feliz Guattari, A Thousand Plateaus (London: Continuum, 1987), pp. 422-526.

58 See Eyal Weizman, 'The Art of War: Deleuze, Guattari, Debord and the Israeli Defence Force' (Mute, 03.08.06), available at www.metamute.org/editorial/articles/art-wardeleuze-guattari-debord-and-israeli-defence-force (accessed 10.10.12).

59 Henri Lefebvre, The Production of Space (Oxford: Blackwell, 1974).

60 Doreen Massey, For Space (London: Sage, 2005), pp. 9-11.

61 Ibid., p. 5.

62 Lefebvre, The Production of Space.

63 Kim Knott, 'Religion, Space and Place: The Spatial Turn in Research on Religion', Religion and Society: Advances in Research, 1 (2010), 40.

64 F. M. Cornford, From Religion to Philosophy: A Study in the Origins of Western) Speculation (New York: Harper Torchbooks, 1958), p. 30, cited by Hannah Arendt in On Revolution (Harmondsworth, UK: Penguin Books, [1963] 1990), pp. 186-7.

65 M. Ostwald, Nomos and the Beginnings of Athenian Democracy (Oxford: Clarendon Press, 1969), p.20

66 Carl Schmitt, The Nomos of the Earth in the International Law of the Jus Publicum Europaeum (New York: Telos Press, 2003).

67 Ibid., p. 42.

68 Claudio Minca and Rory Rowan, 'The Question of Space in Carl Schmitt', Progress in Human Geography, 39:3, 268-89.

69 Claudio Minca, 'Carl Schmitt and the Question of Spatial Ontology', in Stephen Legg (ed.), Spatiality, Sovereignty and Carl Schmitt: Geographies of the Nomos (London: Routledge, 2011), p. 168.

70 John Agnew, 'Territory', in Derek Gregory, Ron Johnston and Geraldine Pratt (eds), The Dictionary of Human Geography (Chichester, UK: Wiley- Blackwell, 2009), pp. 746-7.

71 Ibid.

72 Deleuze and Guattari, Nomadology, pp. 15-16.

73 Mitchell Dean, 'A Political Mythology of World Order: Carl Schmitt's Nomos', Theory, Culture and Society, 23:5 (2006), 1-22.

74 Humphrey acknowledges the existence of 'localised forms of sovereignty', 'nested' within 'higher sovereignties'. From this, it is possible to extrapolate and envisage nomoi 'nestled' within 'higher nomoi'. C. Humphrey, 'Sovereignty', in D. Nugent and J. Vincent (eds), A Companion to the Anthropology of Politics (Oxford: Blackwell, 2004), pp. 418-36.

75 Hans Lindahl, 'Give and Take: Arendt and the nomos of Political Community', Philosophy \& Social Criticism, 32:7 (2006), 882.

76 Anna Jurkevics, 'Hannah Arendt Reads Carl Schmitt's The Nomos of the Earth: A Dialogue on Law and Geopolitics from the Margins', European Journal of Political Theory, 16:3 (2017), 345-66.

77 Arendt, Was ist Politik? Fragmente aus dem Nachlaß (Ursula Ludz, ed.) (Munich: Piper, [1993] 2003), p. 122. 
78 Arendt, On Revolution (New York: Penguin, 2006), p. 275.

79 Khaldun, The Muqaddimah, 1:82.

80 Hannah Arendt, The Human Condition (Chicago: Chicago University Press, 1998), pp. 197-8, 207.

81 Cover, 'The Supreme Court, 1982 Term - Foreword: Nomos and Narrative', Faculty Scholarship Series (1983) Paper 2705, p. 10.

82 Ibid. p. 15.

83 Ibid. p. 8.

84 Quran 2:173.

85 The story of Antigone reveals a fundamental tension between obeying the laws of the sovereign or following the norms of one's faith, bringing to light the contestation of competing orderings.

86 Khaldun, The Muqaddimah.

87 Arendt, The Human Condition, pp. 197-8.

88 Simon Mabon, 'The World Is a Garden: Nomos and the (Contested) Ordering of Life,' Review of International Studies (forthcoming).

89 Of Arab fears of Persian and vice versa.

90 For a detailed discussion of this and Arendt's work on nomos more broadly, see Lindahl, 'Give and Take'.

91 Migdal, Strong Societies and Weak States.

92 Ibid., p. 4. While some may draw parallels with ideas of hybrid sovereignty, such a concept struggles to adequately take into account the interaction of formal and normative structures, particularly the implications of such a struggle for space and the regulation of life.

93 Marisela Montenegro and Joan Pujol, 'Introduction: Bordering, Exclusions and Necropolitics', Qualitative Research Journal, 17:3 (2017), 143.

94 Mbembe, 'Necropolitics', p. 17.

95 United Nations, Arab Human Development Report 2016: Youth and the Prospects for Human Development in a Changing Reality (New York: United Nations, 2016), p. 17.

96 Fouad Ajami, 'The End of Pan-Arabism', Foreign Affairs, 57:2 (Winter 1978-79). 355.

97 Barnett, Dialogues in Arab Politics.

98 Martin Kramer, 'Muslim Congresses', in The Oxford Encyclopedia of the Modern Islamic World (John L. Esperito, ed.) (Oxford: Oxford University Press, 1995), p. 309.

99 See Michael Farquar, Circuits of Faith: Migration, Education, and the Wahhabi Mission (Palo Alto, CA: Stanford University Press, 2016); and Michael Farquhar, 'Saudi Petrodollars, Spiritual Capital, and the Islamic University of Medina: A Wahhabi Missionary Project in Transnational Perspective', International Journal of Middle East Studies, 47:4, 701-21.

100 Simon Mabon, Saudi Arabia and Iran: Soft Power Rivalry in the Middle East (London: I. B. Tauris, 2013).

101 See Martin Kramer, Ivory Towers on Sand: The Failure of Middle Eastern Studies in America (Washington, DC: Washington Institute for Near East Policy, 2001).

102 Barnett, Dialogues in Arab Politics.

103 In Syria this was 56.5\%, in Egypt 55\% and in Yemen 31.6\%. See United Nations Economic and Social Commission for Western Asia, Arab Middle Class: Measurement and Role in Driving Change (New York: United Nations, 2014). 
104 International Labour Organization, 'Rethinking Economic Growth: Towards Productive and Inclusive Arab Societies' (ILO, 2012), available at www.ilo.org/ wcmsp5/groups/public/---arabstates/---ro-beirut/documents/publication/wcms_ 208346.pdf, pp. 6, 47.

105 United Nations, Arab Human Development Report 2016, table 2.

106 Mara Revkin, 'Egypt's Untouchable President' (Foreign Policy, 25.11.12), available at https://foreignpolicy.com/2012/11/25/egypts-untouchable-president (accessed 25.11.12).

107 Ariel Ahram, 'On the Making and Unmaking of Arab States', International Journal of Middle East Studies, 50:2 (2018), 323-7. See also Ariel I. Ahram, Break all the Borders: Separatism and the Reshaping of the Middle East (Oxford: Oxford University Press, 2019).

108 Mabon, Saudi Arabia and Iran.

109 Mabon, 'The World Is a Garden'. 